\title{
Unusual bronchial foreign body without atelectasis
}

\author{
Yasuki Uchida, Mitsuhiro Tsukino, Eiichi Hayashi
}

Department of Respiratory Medicine, Hikone Municipal Hospital, Hikone, Shiga, Japan

\section{Correspondence to}

Dr Yasuki Uchida,

ranmalunlun@hotmail.co.jp

\section{To cite: Uchida $Y$}

Tsukino M, Hayashi E. BMJ Case Rep Published online: [please include Day Month Year] doi:10.1136/bcr-2013009452

\section{DESCRIPTION}

An 8-year-old girl presented at the emergency department with coughing and wheezing. She had been playing with a ballpoint pen in her mouth when her parents called her, and the tip of the pen disappeared at this time point. No abnormality was noted in the region from her mouth to the larynx, and the chest radiography results were unremarkable. The wheezing and coughing persisted; therefore, she was admitted to the paediatrics department of our hospital the next day. CT revealed the presence of the plastic tip of the pen in the truncus intermedius (figure 1). The tip was parallel to the bronchus; therefore, the airway had been maintained. The tip of the pen was removed using alligator forceps and a flexible bronchoscope via a laryngeal mask (figure 2 ).

In previous studies on foreign body aspiration, radiological test results had high false negativity that was inappropriate for correct diagnosis, and the chest radiography results were unremarkable in $6-80 \%$ of the patients. ${ }^{1}$ The most frequent radiography finding was atelectasis. ${ }^{2}$ In our case, the tip of the pen was hollow and was parallel to
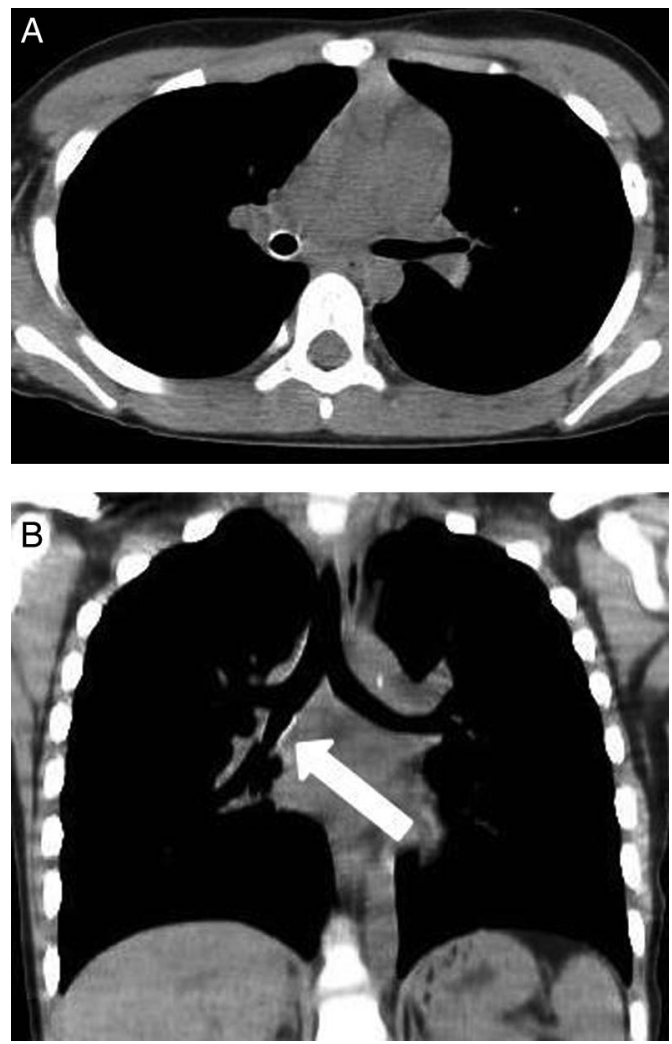

Figure 1 CT scan of the chest showing the tip of the pen in the truncus intermedius. (A) Coronal section with the arrow showing the foreign body. (B) Sagittal section showing the arrow pointing to the foreign body. he bronchus; therefore, atelectasis did not occur. Although there are no specific symptoms and signs for a clear-cut diagnosis of foreign body aspiration, a history of witnessed foreign body aspiration, hospital admission within $24 \mathrm{~h}$ from respiratory symptom onset and wheezing are appropriate indications for bronchoscopy. ${ }^{1}$

\section{Learning points}

Radiological studies are not enough for correct diagnosis

- Although there are no specific symptoms and signs for ab clear-cut diagnosis of foreign body aspiration, a history witnessed foreign body aspiration, hospital admission within $24 \mathrm{~h}$ from respiratory symptom onset and wheezing are o appropriate indications for bronchoscopy.
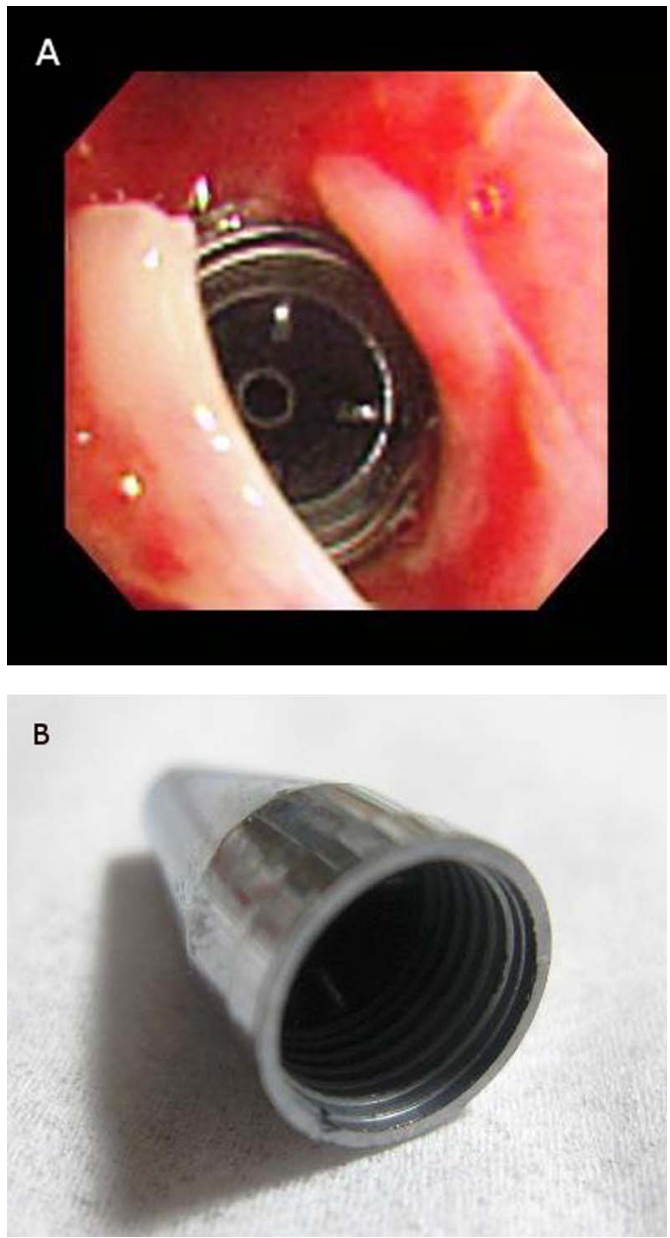

Figure 2 (A) A bronchoscopic image showing the tip of the pen around the granulation tissue in the truncus intermedius. (B) The tip of the pen after removal. 
Competing interests None.

Patient consent Obtained.

Provenance and peer review Not commissioned; externally peer reviewed.

\section{REFERENCES}

1 Ezer SS, Oguzkurt P, Ince E, et al. Foreign body aspiration in children: analysis of diagnostic criteria and accurate time for bronchoscopy. Pediatr Emer Care 2011;27:723-6.

2 Ade M Fraga, Reis MC, Zambon MP, et al. Foreign body aspiration in children: clinical aspects, radiological aspects and bronchoscopic treatment. I Bras Pneumol 2008;34:74-82.

Copyright 2013 BMJ Publishing Group. All rights reserved. For permission to reuse any of this content visit http://group.bmj.com/group/rights-licensing/permissions.

BMJ Case Report Fellows may re-use this article for personal use and teaching without any further permission.

Become a Fellow of BMJ Case Reports today and you can:

- Submit as many cases as you like

- Enjoy fast sympathetic peer review and rapid publication of accepted articles

- Access all the published articles

- Re-use any of the published material for personal use and teaching without further permission

For information on Institutional Fellowships contact consortiasales@bmjgroup.com

Visit casereports.bmj.com for more articles like this and to become a Fellow 